\title{
Impact of Narega on Rural Areas of Hoshiarpur
}

\author{
Kanika, Nancy,Dr.B.P Gupta \\ Assistant Professor, Rayat Bahra Institute of Management, Hoshiarpur(Punjab),India. \\ krishna5kanika@gmail.com \\ Assistant Professor, Lovely Professional University, Phagwara(Punjab),India \\ nancy.sahni@gmail.com \\ Director, Rayat Bahra Institute of Management, Hoshiarpur(Punjab),India. \\ bpgupta04@gmail.com
}

\begin{abstract}
Since its enactment in 2005, the National Rural Employment Guarantee Act (NREGA) has been implemented in 200 districts in India, it is an employment programmer coupled with a rural upliftment scheme to create social equity, an empowerment scheme and a crucial public investment method to create durable assets The State is made legally binding to satisfy the right to work and wage payment within 15 days as per this scheme. State Governments are liable to pay unemployment allowance to wage seekers if it fals to provide employment within the stipulated time. The main objective of our study to check the awareness level of people about NREGA scheme, its effectiveness and Women empowerment on the basis of participation level and income household in the Hoshiarpur district of Punjab. The study conducted is descriptive as well as exploratory and data is collected through structured questionnaire. This study has resulted into positive impact on empowering the women.
\end{abstract}

Keywords: Nrega; Women Empowerment; Participation; Awareness.

\section{Academic Discipline And Sub-Disciplines}

Management

\section{SUBJECT CLASSIFICATION}

National Rural Employment Guarantee Act

\section{TYPE (METHOD/APPROACH)}

Descriptive as well as exploratory and data is collected through structured questionnaire

\section{Council for Innovative Research}

Peer Review Research Publishing System

Journal: International Journal of Management \& Information Technology

Vol.4, No.1

editor@cirworld.com

www.cirworld.com, member.cirworld.com 


\section{INTRODUCTION}

"Priority" should be given to women in the allocation of work "in such a way that at least one-third of the beneficiaries shall be women".

[Schedule II, Para 6, NREGA]

Economic security is one of the main components of human security. It constitutes the crux of social security, in the conventional sense. Economic security requires employment and an assured source of a basic income adequate for meeting one's basic needs. A primary objective of state policy should generate greater productive work opportunities in the growth process itself, by concentrating on sectors, sub-sector and technologies which are more labororiented, in regions characterized by higher rates of unemployment and under-employment. Recognizing the high incidence of under-employment and increasing actualization of labor, there is a need to enhance employment opportunities for the poor, particularly for those who are in seasonal occupation

The National Rural Employment Guarantee Act (NREGA) is one of the most progressive legislations enacted since independence. Its significance is evident from a variety of perspectives. First, it is a bold and unique experiment in the provision of rural employment - in India and indeed in the world at large. Second, it is the first expression of the right to work as an Enforceable legal entitlement. In a country where labor is the only economic asset for millions of people, gainful employment is a prerequisite for the fulfillment of other basic rights - the right to life, the right to food, and the right to education

There is much that the NREGA promises from the perspective of women's empowerment as well. Most boldly, in a rural milieu marked by stark inequalities between men and women - in the opportunities for gainful employment afforded as well as wage rates - NREGA represents action on both these counts. The act stipulates that wages will be equal for men and women. It is also committed to ensuring that at least $33 \%$ of the workers shall be women. By generating employment for women at fair wages in the village, NREGA can play a substantial role in economically empowering women and laying the basis for greater independence and self-esteem.

\section{Growth}

Employment is the main source of livelihood and self-fulfil ment for most women and men. It is critical to the way women and men live and view their lives. A well-nurtured and productive labour force contributes towards a dynamic economy and equitable society. Lack of access to employment, that is decent and remunerative, lowers selfesteem and leads to denial of basic needs of the individual and the family, and can lead to social instability. It is, therefore, important to work towards the goal of decent and remunerative work for all women and men seeking such work, in conditions of freedom, equity, security and human dignity.

India has witnessed an impressive and steadily rising rate of economic growth for about two decades now. The prospects of a continuation of this high economic growth in the medium term are also high. And yet, the challenge of employment, especially good quality and remunerative employment remains formidable. Although there has been a reversal of the declining trend in employment growth in the post-2000 period, there has also been a simultaneous increase in unemployment rates as employment growth has not kept pace with growth in labor supply. Unemployment rates have been high and increasing, especially amongst certain groups - such as youth, women and young graduates. Furthermore, about 10 million new entrants to the labor force are expected each year, for which jobs would need to be generated.

Over half the work force, continues to depend on the agriculture even though it accounts for less than fifth of the total GDP. This implies a vast gap in incomes and productivity between agriculture and non-agriculture sectors. This is mainly due to inadequate growth of productive employment opportunities outside agriculture. The organized sector that offers work that would be considered decent employs less than 10 per cent of the workforce and, In recent years, has been characterized by low and declining employment intensity of output growth. An overwhelming majority of workers are currently employed in the unorganized sector where most of the new jobs are also created. In addition, most new jobs that are being created in the organized sector are informal in nature. These jobs are mostly characterized by low earnings, poor conditions of work and lack of social protection and organization.

\section{SCOPE OF THE STUDY}

The scope of the study lies in finding out the impact or effectiveness of NREGA in HOSHIARPUR especially in rural areas.

\section{OBJECTIVES OF THE STUDY}

1. Women empowerment on the basis of participation level and income household

2. Awareness level of people about NREGA scheme.

3. Effectiveness of NREGA scheme in rural areas.

\section{Limitations of the study}

- Many of the respondents were not open with their responses.

- Unwillingness and inability of the respondent to provide true information.

- The sample size of research is limited, because of time and cost factor.

- Due to the fact that most of the respondents were young, the questions might not have been answered with due sincerity. 
- The information collected may not be sufficient and reliable.

- The study was time bound.

\section{REVIEW OF LITERATURE}

Sharma et al (1977) are convinced that Rural Development as a concept and a reality has suffered intellectual importation heavily biased by philosophical-methodological assumptions quite unrelated to the actual configuration of problem-situation. Over the years, it has created ambivalence and equivocation among those who regard rural reconstruction as a faith and a mission to the soil. It would be neither charitable nor compatible to blame wholly the lack of policy emphasis or even its clear articulation to account for the inadequate pace of rural development but the very nature of the process is extremely complex, requiring multidimensional approach and interdisciplinary knowledge. The effort also suffered owing both to paucity of resources and lack of commitment, not altogether unexpected in nation-building activities of developing countries having traditional societies.

Sinha (1986) in an official paper regarding IRDP, opines that things have gone wrong at a multitude of levels. Firstly, the DRDA officials charged with plan formulation have neither the necessary skills nor the planning experience. Secondly, the pressure for achieving quantitative targets, the related malpractices and the consequent „policing" role thrust upon the DRDA leave little time for such „theoretical" exercises as planning. Thirdly, detailed directives issued by the Centre and by State governments have, in practice, left little room for maneuver on the basis of local conditions.

Shekhar (1987) a journalist states that an evaluation study of the Integrated Rural Development Programme (IRDP) in the district of Hamirpur, H.P. has revealed that 49 per cent of the families covered under the programme have crossed the poverty line. The percentage of the scheduled castes families which have crossed the poverty line is 49.1 and for others it is 48.92 .

Singh and Lal (1987) in their study came to the conclusion that about 48 per cent of the beneficiary households had crossed the poverty line. In an evaluative study entitled "Financing Under Rural Development Programme", the State Bank of Patiala (1987:14) concludes that 42 among 100 persons seem to have crossed the poverty line but according to these beneficiaries, the additional income so generated has not improved their living conditions to the desired extent since the market price of essential consumer goods has increased so much that the additional income generated by them has been nullified. However, almost all the beneficiaries have claimed that they have increased their annual income and now they are living in somewhat better conditions than those prevailing before availing loans under IRD programme.

Srivastava and Singh (1987) have come to the conclusion based upon the Proceedings of Dialogical Session, 1985 that asset creation under NREP and RLEGP should have a long-term income-employment generation effort rather than taking up only short-term projects at ad hoc basis. Creation of durable assets for strengthening economic infrastructure in rural area may provide long-term income-employment generation effect. Similarly, asset creation in terms of a large number of irrigation work will improve agriculture and will „reduce the risk involved in cultivation" and will "lead to grater labour absorption"

Singh (1988) in his study conducted for Agricultural Banking Department of State Bank of India concludes that; (1) there is a lack of infrastructural facilities like roads, market, veterinary hospitals and milk collection centre, for the success of the schemes; (2) technical guidance to the beneficiaries is not forthcoming properly so as to help them use their assets economically; (3) there is a lack of coordination among the bank and block officials; (4) insurance claims of animals are not being settled expeditiously; (5) under-financing of the project gives rise to poor return and renders the scheme unviable.

Sharma (1988) in his study concludes that the experiences gained so far has shown that IRDP could not be organically interlinked with other on-going activities/programmes of the government and it has become clear that the benefits from other programmes, particularly social services, could not reach the targeted households.

Desai in his voluminous book, Rural Development (1988) inferred some results based on the study conducted by National Bank of Agriculture and Rural Development (NABARD) in 15 states to scan the performance of DRDA. His study found that DRDA and other concerned departments did not play any effective role in ensuring the supply of the right quality of assets to the programme participants. He (Vol. vi, 633) found that out of 868 sample beneficiary households initially having an annual income of less than Rs.3500, per annum, 49.42 per cent were able to achieve an annual income level of Rs.3500 and above after their coverage under the IRDP.

Kulkarni et al (1989) conducted a study in Bijapur district of Karnataka. They found that different socio-economic factors affect the success or failure of different IRDP schemes. According to them, the success of IRDP mainly depends upon the level of education, family size, ownership of livestock, durable assets and occupational structure. Hence, it is necessary to take up certain aspects of the environment, including characteristics of the beneficiaries. The study highlights that one of the reasons for poor performance of IRDP was the delay in actual sanctioning of loans and releasing of the subsidy amount by the development authorities. It is suggested that single window approach for both subsidy and loan would reduce the time gap and transaction cost of borrowing to the beneficiaries.

Venkata Reddy (1989) The problem of surplus population subsisting on land and the consequential increase in rural unemployment and under employment leading to poverty in India has been stressed by several competent authorities since the report of the famine commission of 1880 . However the evaluation reports points out certain gaps. Elements of unproductive works undertaken in the scheme, lack of continuity of works under the scheme the absence of agency to prepare blueprints for different type of works on continuous basis, lack of effective revision over the works undertaken, leading to corrupt practices, shortages of farm wage labour due to concurrent EGS with adverse effect on agricultural operations. There was no authoritic information about the employment seekers on there was no adequate knowledge of the nature of works which should receive priority under the EGS. At district level 
of entire work relating to planning, implementation, supervision etc. will be the responsibility of the District Rural Development Agency (DRDA). The review of NREP shows that the employment generation target has been consistently achieved.

Judge (1989) conducted a survey in Hoshiarpur district of Punjab to evaluate the performance of special component plan (SCP) which is a part of IRDP. Regarding economic mobilization of sample respondents, after getting loan, he concludes that all those respondents who took a loan upto Rs.3,000, 34.18 per cent pointed out that there was no effect, whereas 39.24 per cent and 26.57 per cent respectively said that thei $r$ income increased significantly and marginally. But in the case of those respondents who took loans amounting to Rs.3,001 to Rs.6,000, the increase in income was significant. It may, however, be pointed out that most of the respondents took loans only once which, in the case of loan for milch animals, is not economically viable.

Tenaja (1989) states that despite tall claims about the success of various anti-poverty measures such as IRDP, NREP RLGP and TRYSEM, most of the labour households are still not able to meet their minimum consumption requirements. These are people who do not have a bare sufficiency of anything - neither food, nor clothing nor shelter, what to speak of education or medical care. The fact we find such utter destitution here in Punjab (reputed to be the home of India"s most progressive farmers) raises doubts about the designing and implementation of the poverty eradication programmes which have generally taken the forms of loan facilities, subsidies, grants, etc.

Karunakaran (1998) felt that focusing on non-agricultural employment in the rural areas would be crucial to poverty reduction. There is a correlation in the employment in both agricultural, non-agricultural sectors and poverty levels. The shrinkage in the agricultural employment would normally lead to increase in the employment in non-agricultural sector which would result in the decline of the poverty level. Promotion of agricultural growth in the form of improving irrigational facilities through watershed development programmes would result in non-agricultural growth. Non-governmental organizations have a critical role to play in the area of market development. It was also felt that highly professionalized marketing system and reservation/sops for the tiny industry would go a long way in achieving the desired results.

Saxena (1998) has also emphasized the need for providing employment in the non-agricultural sector. According to him the following are the gaps in the existing policy. a) Lack of focus; b) Appropriate support not being extended; c) Inadequate industrial mechanism; and d) Lack of research and development; e) IRDP not being used for forging backward and forward linkages to support micro enterprises.

\section{RESEARCH METHODOLOGY}

Research Methodology is a design to systematically solve the problem. In research methodology we not only talk of research methods but also consider the logic behind the methods it includes the overall research design, the sampling procedures, the data collection methods, the field method \& analysis procedures.

3.1 Research Design The research design is purely and simply the framework of plan for a study that guides the collection and analysis of data. Descriptive research exploratory design was used for this research.

\subsection{Sources of Data}

a) Primary Data: The type of data collected comprises of primary data. Primary data is the first hand data collected from individual. It has been collected through structured questionnaire.

b) Secondary Data: Published Sources such as Journals, Newspapers, and Magazines etc.

Websites are also searched to find data.

Data is collected from websites of NREGA and various other government related sites

\subsection{Sample Procedure}

The method used for data collection is "questionnaire method "the questionnaire is a structures one. The words used are simple and helps in avoiding confusion and misunderstanding among the respondents.

Sampling size: The total sample size is 50 .

Sampling technique: Convenient Sampling technique is used for this research.

3.4 Tools of Analysis: Research is being done by using the questionnaire. The questionnaire is being made and filled by the workers who are engaged in the NREGA SCHEME and then result is being made out through the percentage method as the respondents respond.

\section{DATA INTERPRETATION}

Various tools are used to analyze the data tools like pie ,bar chrts and percentage method is used to find out results.

\section{Findings}

- $\quad$ Today there is $44.69 \%$ women participation in MNREGA and it is increasing day by day over all in our survey we find that women participation in MNREGA is more than men

- $55 \%$ of women are the single earner for their family they are aware of their rights

- $\quad 40 \%$ respondents got job in NREGA and they are not employed previously

- $57 \%$ female participants said that the wages had helped them avoid illness in the family.

- $30 \%$ of the widows advocate of having upheld their self respect because of MNREGA

- $\quad$ To those widows not getting pension, NREGA offers relief. 
- $69 \%$ of the female respondents reported having faced less hunger due to employments

- Apart from keeping their own wages, $40 \%$ women have a substantial say in how to spend it

- $60 \%$ respondents has not any objections to earn income of women equal to men

- More than $75 \%$ of the respondents are of SC,ST category

- Women as individuals have gained because of their ability to earn independently, made possible due to the paid employment opportunity under NREGS.

- Independent and monetized earnings have increased consumption choices and reduced economic dependence. This has helped women in registering their tangible contribution to the household's income.

\section{Suggestions}

- In our study we find that overall $70 \%$ respondents are known about the NRGEA's act facilities'

- Timely payment of wages through individual accounts of women workers encourages participation, and greater control over earnings. And it enhance the independence level of the women.

- Working conditions need to be made more conducive by enforcing and strengthening existing provisions and adding new ones Crèche provision may be linked with the Anganwadi or Integrated Child Development Services (ICDS) centres, panchayat bhavans, local school buildings, etc, to make them more practical.

- In our study we find that there is not any travel allowance given to the workers if the job site is far from the home of the respondents we sugget that travel alloeance is given to the workers if job site is more than $15 \mathrm{~km}$ form their home town

\section{CONCLUSION OF THE STUDY}

Empowerment of rural women has emerged as an unintended consequence of NREGS. Women have benefited more as workers than as a community. Women as individuals have gained because of their ability to earn independently, made possible due to the paid employment opportunity under NREGS. Independent and monetized earnings have increased consumption choices and reduced economic dependence. This has helped women in registering their tangible contribution to the household's income. The overall effects of these have translated into an increased say for women in household affairs. Women as a community, however, have been slow in realizing the potential benefits of the scheme. Nevertheless, their increased presence in the gram sabha, the increasing number of women speaking out in the gram sabha, frequent interactions with government officials and PRI representatives, and access to banks and post offices are new developments. Additionally, the female mate system has reversed the traditional gender roles, albeit in a limited manner.

\section{BIBLIOGRAPHY}

$$
\text { Anish }
$$

Vanaik,

Siddhartha

(2008) "Bank

payments:

End

of Corruption in

NREGA?" Economic and Political Weekly, 43 (12): 33-39

Arun Jacob, Richard Varghese (2006) "NREGA Implementation-I: Reasonable

$$
\text { Palakkad, Kerala, Economic and Political Weekly, } 41 \text { (48): } 4943-4945
$$

Beginningin

[3] Aruna Bagchee (2005) "Political and Administrative Realities of Employment Guarantee Scheme", Economic and Political Weekly.

[4] Chhaya Datar (2007) "Failure of national employment Guarantee Scheme in Maharashtra", Economic and Political Weekly, 42 (34): $3454-3456$

[5] Drèze, Jean and Naresh Sharma (1998): "Palanpur: Population, Society and Economy" in Peter Lanjouw and Nicholas Stern (ed.), Economic Development in Palanpur over Five Decades (Oxford: Clarendon Press)

[6] Employment Guarantee", Frontline, Vol 26, No 1, 3-16 January

[7] Gaiha, R. (2005) 'Does the Employment Guarantee Scheme benefit the rural poor in India? Some recent evidence', Asian Survey, November/December 2005, Vol. 45, No. 6

[8] Jandu, Navjyoti (2008): "Employment Guarantee and Women's Empowerment in Rural India.

[9] Kannan, K. P (2005) 'Linking employment guarantee to human development', Economic and Political Weekly, October 15

[10] Pankaj, Ashok (2010) "Empowerment effects of the NREGs: A study of four States", Economic and Political Weekly, July 24

[11] Pinaki Chakraborty (2007) "Implementation of A preliminary appraisal, Economic \& Political Weekly, 42 (7): $548-551$.

[12] Prakash Louis (2006) "NREGA Implementation - II Birth Pangs in Bihar", Economic and Political Weekly, 41 (48): 4946

[13] Puran Singh

Kurukshetra, 54 (7): $42-43$

(2006) "National Rural Employment Guarantee Scheme",

[14] Mehta, Varsha (2010) "NREGA: Bane or boon"

[15] Randall Wray (2006) "Lessons from Argentina's Employment Guarantee" Economic and Political Weekly; 41 (23): $2293-2296$ 


\section{ABOUT THE AUTHORS}

KANIKA, Assistant Professor at Rayat and Bahra Institute of Management is an MBA(Finance), UGC Net qualified. She has over three years experience of teaching in postgraduate and undergraduate education programmes.

NANCY, Assistant Professor at Lovely Professional university is an MBA(Finance), UGC Net qualified. She has over five years experience of teaching in postgraduate and undergraduate and executive education programmes. She has taught more than 20 subjects in her teaching career. She has been appointed as a member of several committees at university level.

Dr. B.P Gupta, Director at Rayat and Bahra Institute of Management is an MBA(Finance), UGC Net qualified. He has fifteen years of experience in teaching as well as industry. He was a visiting professor of strategic management and operations at various institutes. He was appointed as a member of several committees. 